\title{
With or Without Community Participation: A Lesson from Joint Forest Management in the Eastern Arc Mountains, Tanzania
}

\author{
Sangeda Anthony Zozimus \\ Department of Animal, Aquaculture and Range Sciences, Sokoine University of Agriculture, Morogoro, Tanzania \\ Email address: \\ sangedaaz@gmail.com \\ To cite this article: \\ Sangeda Anthony Zozimus. With or Without Community Participation: A Lesson from Joint Forest Management in the Eastern Arc \\ Mountains, Tanzania. Agriculture, Forestry and Fisheries. Vol. 6, No. 4, 2017, pp. 102-110. doi: 10.11648/j.aff.20170604.11
}

Received: May 6, 2017; Accepted: May 16, 2017; Published: July 5, 2017

\begin{abstract}
Participation is now a dominant conservation narrative in Tanzania as the government is advocating partnership with local communities through Joint Forest Management (JFM). However, conservationists claim that participation does not lead to sustainable conservation and that there is a gap between rhetoric and practice. We assessed stocking and disturbance levels in forests with JFM and compared them with those without. The comparison was done for selected forests within Eastern Arc Mountains in Tanzania with similar ecological characteristics. Systematic forest inventory was employed and 152 circular plots were sampled. Stocking was higher in forests with JFM than forests without for both montane and lowland forests. The difference was statistically significant across all the vegetation types except in woodland ( $p=0.9049)$. However, forest reserves under JFM were more disturbed than those without. Even though, the disturbances were sustainable and ecologically good as they were below the mean annual increment and therefore considered beneficial to the forest in terms of stimulating regeneration of the harvested tree species. The most harvested tree species in montane forest was Ocotea usambarensis while in the lowland forests were Cedrela odorata, Milicia excelsa, Combretum molle and Albizia petersiana. Lack of incentives, benefit sharing mechanisms and market demands led to weak enforcement of set regulations. As a result, JFM have failed to stop illegal harvesting and these forests have become focal points for disturbances. Therefore, there is a need for taking corrective measures before scaling up of JFM in other parts of the country.
\end{abstract}

Keywords: Participation, Stocking, Forest Disturbance, Kimboza Forest Reserve, Tanzania

\section{Introduction}

The Eastern Arc Mountains have been influenced by human related disturbances for centuries [1] mainly through activities including timber harvesting, mining, hunting, charcoal making, bush fires and grazing [2, 3]. The present structure and species composition of these forests are largely a result of these activities [4, 5]. For a long time there has been interest in conserving the forests. Approaches to redress the situation include both fortress and participatory conservation.

The fortress conservation (also called 'fences and fines') was a colonial approach that emphasized separation of people and nature for the purpose of creating 'pristine' environments. The protected areas limited local people's access to forest resources and undermined local institutions in the management of forest resources [6, 7]. Tanzanian government inherited the same approach and continued this practice even after independence by creating more forest reserves. The creation of more reserved areas after independence led to new resource use conflicts with local communities. As a result, there has been little incentive for local people to manage and utilize the forest resources sustainably [8]. Consequently, deforestation and forest degradation increased even in Forest Reserves (FRs) with regular patrols by forest guards. This reality coupled with the inability of the government to continue to finance "fortress conservation" policies, triggered re-thinking in favour of community participation [9].

Participation is now a dominant conservation narrative in Tanzania as the government is advocating partnership 
with local communities through Joint Forest Management (JFM). Since United Nations Conference on Environment and Development in Rio de Janeiro in 1992, participatory conservation has increasingly licensed a panacea to the challenges of deforestation and forest degradation in developing countries $[10,11]$. In Tanzania, the participatory approach is organised into Community Based Forest Management (CBFM) and Joint Forest Management (JFM). Under JFM, villagers enter into Joint Management Agreements (JMAs) to share responsibilities and benefits between the forest owner and the Government [12]. JMAs are common in Tanzania in almost all types of forests such as miombo woodlands, mangroves and coastal forests, and very common in montane forests of Eastern Arc Mountains [13].

However, community participation has been criticised that it does not lead to development i.e. has few local benefits, or it benefits elites [14]. Others argued that there is a gap between rhetoric and practice and sometimes corruption [15]. The participatory approach is being captured by powerful conservationists, and frequently leads to 'business as usual'. There is also no much investigation into institutional failure because many analysts prefer to report successful ventures [16, 17]. Therefore the central research question of this paper is to seek whether there is reduced disturbance (less new removals) as a result of community participation? If any, are they good or bad ecologically? Are the JMAs more effective? These questions are relevant to provide supporting evidence now as the Government and NonGovernmental Organisations are massively investing in scaling up JFM in Tanzania.

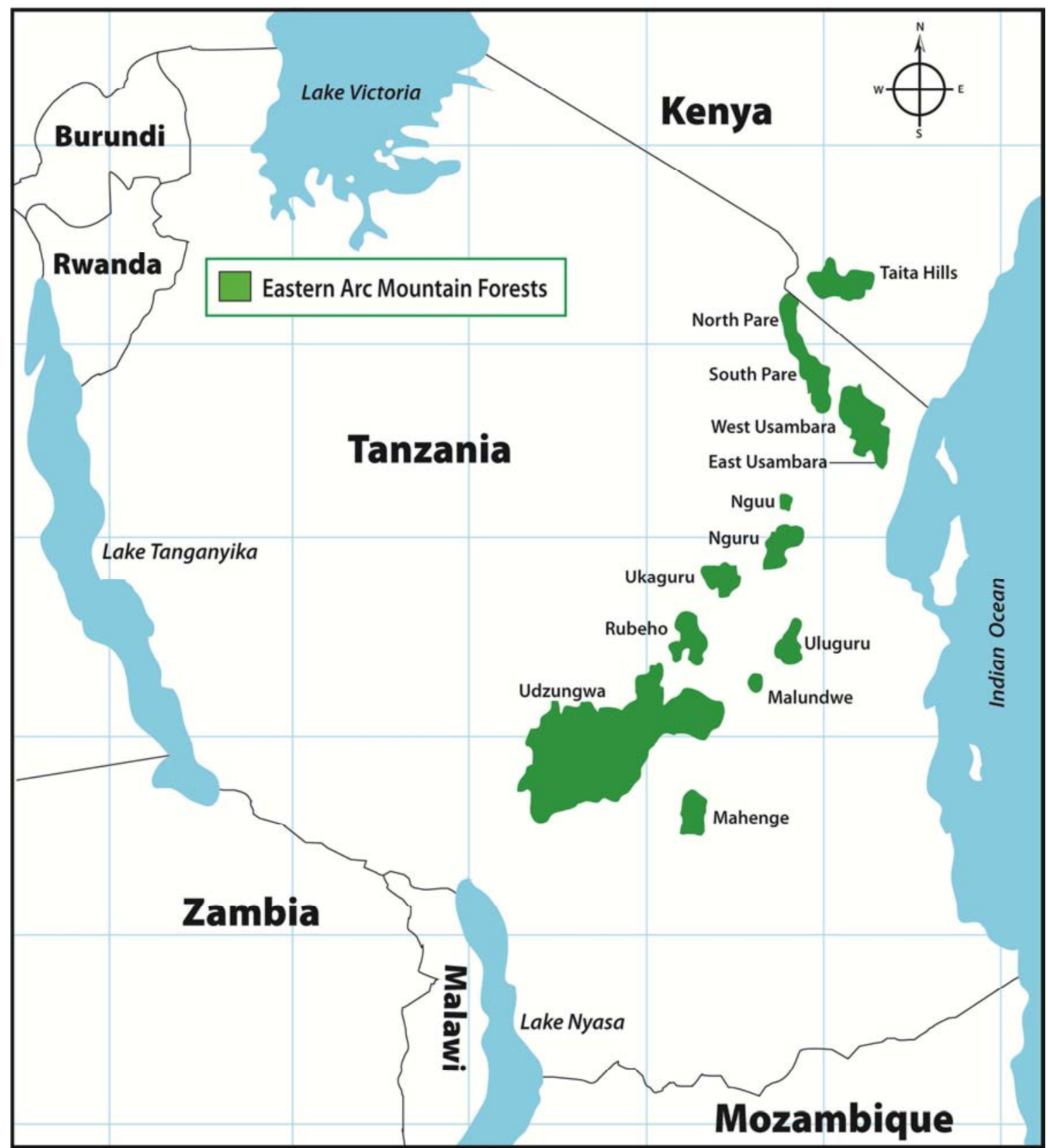

Figure 1. Map of Eastern Arc Mountains. 


\section{Materials and Method}

\subsection{Study Area}

Field work was conducted in the Eastern Arc Mountains (Figure 1) particularly in Morogoro and Iringa regions in Tanzania. These regions comprise the largest area of catchment forests and have a long history of JFM with signed JMAs. The selected FRs in Morogoro region was Kimboza (with JFM) and Ruvu (without JFM). Kimboza FR has an area of 405 ha situated at an altitude of 300 to $400 \mathrm{~m}$. a.s.l. The forest is composed of natural vegetation mainly lowland rainforest tree species dominated by Parkia filicoides, Bombax rhodognaphalon and Sterculia appendiculata with four patches of scattered woodland species, two patches of exotic tree species of Tectona grandis (Teak) along the road and Cedrela odorata which are extensively distributed almost everywhere in the forest to the extent of dominating the lowland tree species (Personal observation). Ruvu FR (2 983 ha) located near Kimboza has no JMA therefore it was used as a control. It is at an altitude of 200 to $480 \mathrm{~m}$ a.s.l. Both Kimboza and Ruvu FRs have mean annual rainfall up to 1 $800 \mathrm{~mm} \mathrm{y}^{-1}$ with similar vegetation types with the exception of exotic trees (Cedrela odorata and Tectona grandis). Both FRs are important catchment forests draining water to Ruvu River which provides water to Morogoro town, the Coastal Region and Dar es Salaam - the main commercial city in the country. Economic activities (disturbances) in these forests include ruby mining and encroachment for small-scale farming, charcoal making and hunting. Logging of Milicia excelsa, Khaya anthotheca and Aningeria pseudoracemosa had taken place in the 1980s. Cedrela trees that were introduced for gap filling (trial plots) have invaded the forest, replacing the indigenous canopy trees.

In Iringa Region, a forest under JFM called New DabagaUlongambi (NDU FR) was selected. NDU FR (3 $700 \mathrm{ha}$ ) is a montane forest with patches of bamboo. The forest lies between 1760 and 2060 m.a.s.l. Kising a-Lugalo (KL) FR was used as a control site as it was in the neighbourhood of NDU FR with similar vegetation types. KL FR (14 164 ha) covers an extensive area of undulating plateau with an elevation ranging from 1700 to 2332 m.a.s.l. The FR is a mosaic of montane forest. Both these catchment forests have a mean annual rainfall ranging from 1500 to $2000 \mathrm{~mm} \mathrm{y}^{-1}$ and are source areas for the small Ruaha River used for hydropower production. Socio-economic activities in these FRs include gathering of building poles, bamboo for basket making and hunting of Hyrax, Red Duiker and Bush pigs. In many places cultivated fields are immediately adjacent to the FR boundary, cattle and sheep are grazed in the reserve and fuelwood is collected. Medicinal plants e.g Prunus africana are also collected for local use [18].

\subsection{Ecological Data Collection and Analysis}

A pilot survey was done in all FRs in order to arrive at an appropriate number of sample plots. The number of sampling plots (n) required to attain a desired precision at specified sampling error (E) was given using the formula

$$
\mathrm{n}=\mathrm{CV}^{2} \mathrm{t}^{2} / \mathrm{E}^{2}
$$

where $\mathrm{CV}=$ coefficient of variation

$\mathrm{t}=$ obtained from the student's $\mathrm{t}$-distribution table at $\mathrm{n}-1$ degrees of freedom of the pilot study with $95 \%$ confidence.

$\mathrm{E}=$ allowable sampling error.

The number of plots was 38 for NDU FR, 46 for KL FR, 35 for Ruvu FR and 33 for Kimboza FR.

Systematic forest inventory was employed in each forest, sampling $900 \mathrm{~m}$ long transects, starting from the forest edge. Plots were sampled $200 \mathrm{~m}$ apart along each line, with every first plot sampled at half the distance between plots. A total of 152 circular plots were sampled in the four FRs. Nested plots were used, consisting of subplots of $2 \mathrm{~m}$ and $5 \mathrm{~m}$ radius within the main plot of $15 \mathrm{~m}$ radius $(0.07 \mathrm{ha})$ [19]. Stem diameter at breast height $(\mathrm{DBH})$ was measured for all trees, as follows: In subplots with $2 \mathrm{~m}$ radius: trees $>1 \mathrm{~cm}$ to $5 \mathrm{~cm}$ $\mathrm{DBH}$; in $5 \mathrm{~m}$ radius subplots: trees $>5 \mathrm{~cm}$ to $20 \mathrm{~cm} \mathrm{DBH}$; in the main $15 \mathrm{~m}$ radius plots: trees $>20 \mathrm{~cm} \mathrm{DBH}$. The height and basal diameter of three sample trees in a plot were measured. Basal diameters of harvested tree stumps were measured to quantify the removals in each plot. Tree stumps were described as 'old cut' if blackened (cut more than one year before the study). If the stump was fresh, it was regarded as 'new cut'. Other types of human disturbances such as timber harvesting, mining, hunting, charcoal making, bush fires and grazing were recorded for each plot through casual and opportunistic observations.

Microsoft Excel was used to analyze the data. The stocking parameters (Table 1) were calculated using the standard formula adopted from Philip [20]. Percentages of live, old and new cut stems and volume of cut stems were calculated to reflect disturbance (removal of biomass). Since only three trees were measured for height in each plot, the height of the rest of trees were obtained from developed diameter-height equations fitted using regression equation techniques. Diameter-height equations were used to estimate DBH of cut trees. Tree volumes for montane and lowland forests were calculated as average of sums of individual plots using equation (2).

$$
\mathrm{V}_{\mathrm{i}}=0.5 \mathrm{~g}_{\mathrm{i}} \mathrm{h}_{\mathrm{i}}
$$

Where $V_{i}=$ the volume of the $i$ th tree $\left(\mathrm{m}^{3}\right)$

$h_{i}=$ the total height of the $i$ th tree (m)

$g_{i}=$ the tree basal area $\left(\mathrm{m}^{2}\right)$

$0.5=$ the tree form factor.

Tree form factor of 0.5 is recommended for use in natural forests in Tanzania due to deformation of trees and tapering [21].

Mean volume of harvested trees from both montane and lowland forests was calculated as average of sums of individual plots. In woodland vegetation volume was estimated using equation (3) [22]. 


$$
\mathrm{V}_{\mathrm{i}}=4.710^{-5} \mathrm{~d}_{\mathrm{i}}^{2.56}
$$

Where $V_{i}$, is as (i) above, and $d i$ is DBH of the $i$ th tree (in $\mathrm{cm})$.

Statistical analysis was done using two-tailed $t$-tests $(\alpha=0.05)$ to compare stocking parameters between FRs with and without JFM for similar vegetation types.

\subsection{Socio-economic Data Collection and Analysis}

These were collected through Focused Group Discussions (FGDs) and a Questionnaire Survey. A total of 164 respondents were interviewed in four villages including Kidabaga and Luhindo (Iringa) and Kibangile and Changa (Morogoro). FGDs were done with four different social groups in each village including elders, women, youth and village natural resources committee members. Conversations with respondents in group discussions were analysed through content analysis while questionnaire data were analysed by descriptive statistical methods.

\section{Results}

\subsection{Stocking Parameters}

The number of stems per hectare (N) in similar vegetation types was higher in FRs with JFM than those without JFM. The difference was statistically significant across all the vegetation types except in woodland $(\mathrm{p}=$ 0.9049). In lowland forest, the average $\mathrm{N}$ in Kimboza was twice higher than that of the Ruvu FR (Table 1). Generally in all vegetation types, many trees were found in the smallest DBH class $(1-10 \mathrm{~cm})$-not shown in Figure 2 to improve scale.

Table 1. Comparison of stocking parameters (number of stems [N], basal area [G] and volume [V]; mean \pm standard error) in FRs with and without JFM in Iringa and Morogoro, Tanzania.

\begin{tabular}{|c|c|c|c|c|c|c|}
\hline $\begin{array}{l}\text { Forest } \\
\text { Reserve }\end{array}$ & Management regime & Vegetation type/stratum & Location & $\mathbf{N} \pm$ SE (Stems ha $\left.{ }^{-1}\right)$ & $\mathrm{G} \pm \mathrm{SE}\left(\mathrm{m}^{2} \mathrm{ha}^{-1}\right)$ & $V \pm \operatorname{SE~}\left(\mathrm{m}^{3} \mathrm{ha}^{-1}\right)$ \\
\hline *NDU & JFM & Montane & Iringa & $1581 \pm 195$ & $21.5 \pm 2.9$ & $170.5 \pm 31.5$ \\
\hline$* * \mathrm{KL}$ & Without JFM & Montane & & $1018 \pm 183$ & $15.8 \pm 3.3$ & $108.0 \pm 28.1$ \\
\hline \multirow[t]{4}{*}{ Kimboza } & JFM & Lowland & Morogoro & $1117 \pm 254$ & $22.6 \pm 4.8$ & $225.4 \pm 64.2$ \\
\hline & & Miombo & & $363 \pm 323$ & $10.7 \pm 1.3$ & $100.5 \pm 36.4$ \\
\hline & & Cedrela & & $1091 \pm 286$ & $42.6 \pm 20.0$ & $455.9 \pm 383.7$ \\
\hline & & Teak & & $564 \pm 475$ & $27.8 \pm 18.4$ & $232.0 \pm 169.6$ \\
\hline Ruvu & & Miombo & & $344 \pm 107$ & $10.1 \pm 2.1$ & $127.9 \pm 43.1$ \\
\hline
\end{tabular}

$*$ NDU $=$ New Dabaga Ulongambi $* * \mathrm{KL}=$ Kising`a-Lugalo

The overall distribution of number of stems (Figure 2) by DBH classes indicated a normal reversed ' $J$ ' shape trend in all four FRs.

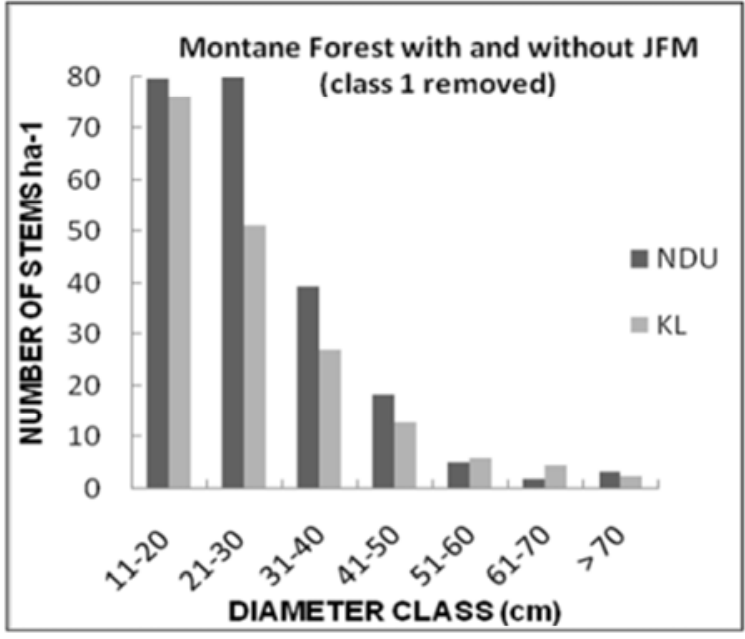

Figure 2(a)

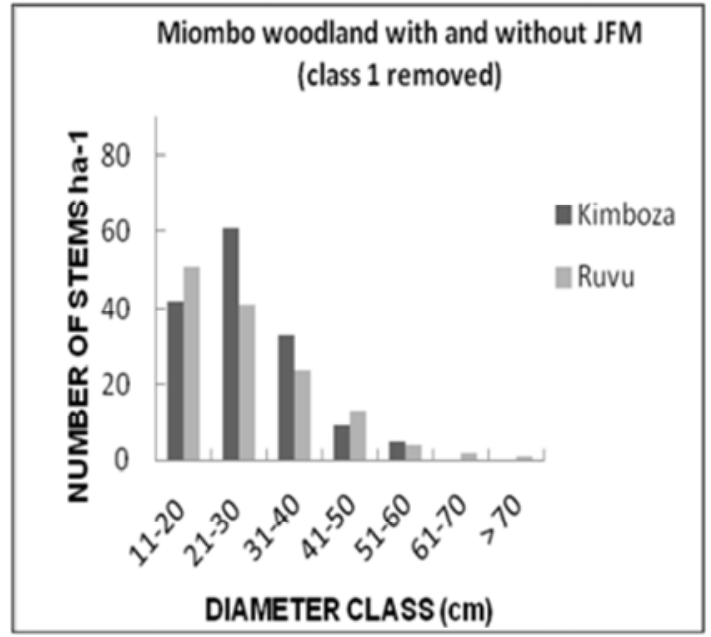

Figure 2(b)

Figure 2. Distribution of number of stems per hectare by DBH classes compared between FRs with and without JFM in (a, left) montane forest at Iringa, and (b, right) miombo woodland at Morogoro, Tanzania. NDU and Kimboza are forests with JFM and KL and Ruvu without JFM. The number stems/ha for the 1$10 \mathrm{~cm}$ diameter class was as follows: $N D U=1344$ stems per ha; KL=839 stems per ha; Kimboza $=212$ stems per ha; and Ruvu=208 stems per ha.

In general, the average stand basal area and volume per hectare were higher in all FRs with JFM than in those without and the difference was statistically significant $(\mathrm{p}=$ 0.0151 for basal area and $p=0.0046$ for volume between 
NDU and KL FRs, and $p=0.0009$ for basal area and $p=$ 0.0037 for volume between Kimboza and Ruvu FRs in Morogoro. However, in woodland the difference was statistically not significant. It was also revealed that within lowland forest basal area and volume in Kimboza FR were double those in Ruvu. Highest stocking values were however recorded in Cedrela odorata plantation within Kimboza FR.

Diameter class $21-30 \mathrm{~cm}$ had slightly more stems per hectare than expected for NDU and Kimboza FR. This might

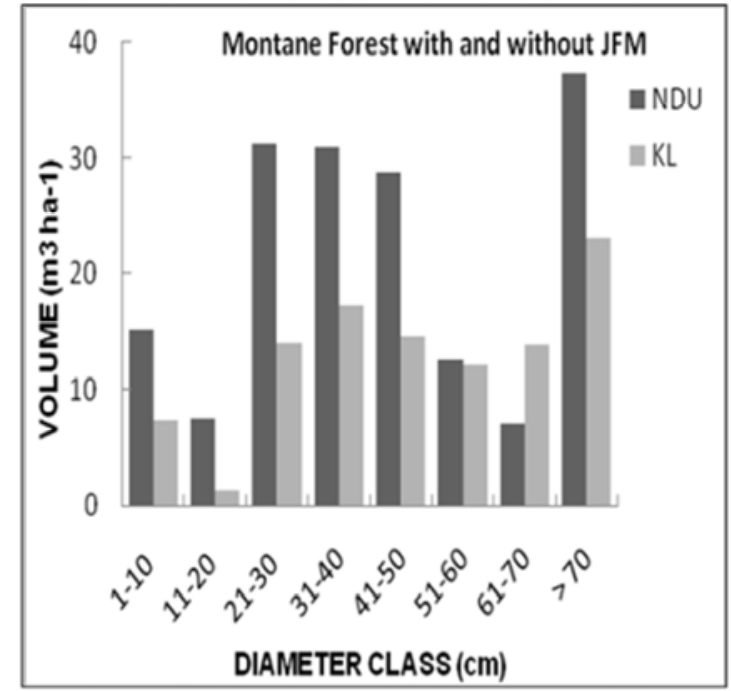

Figure 3 (a) be due to effect of introducing JFM where communities were strictly not allowed to harvest poles in these forests in last 15 to 20 years. It is assumed that during that time this diameter class 21-30 cm was of a pole size suitable for construction. Figure 3 compares the distribution of timber volume by diameter classes between FRs with and without JFM. It can be observed that Kimboza do not have woodland tree species (Figure 3) that are in higher diameter classes (above $61 \mathrm{~cm}$ ).

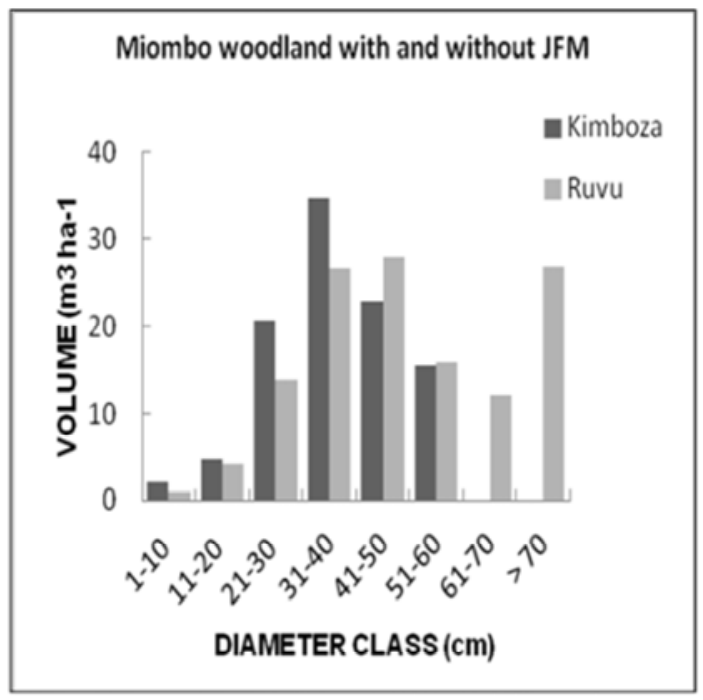

Figure 3 (b)

Figure 3. Distribution of volume per hectare by DBH classes compared between FRs with and without JFM in (a, left) montane forest at Iringa, and (b, right) miombo woodland at Morogoro, Tanzania. NDU and Kimboza are forests with JFM and KL and Ruvu without JFM.

According to Table 1, Forest Reserves with JFM are doing better in terms of stocking parameters. Presence of many regenerating trees in all surveyed FRs were probably due to presence of past disturbances because most regenerating tree species were fast growing pioneer species e.g. Macaranga kilimandscharica in montane sites. They regenerate vigorously in clear-felled areas, secondary forest, forest edges and disturbed places. This was enhanced because of increased gaps, light, raised soil temperature, and reduced nutrient competition [23, 24]. It was also a manifestation of the ecosystems resilience and an indication of healthy forest [20].

\subsection{Forest Disturbance}

FRs with JFM had higher removed volumes per hectare than those without JFM (Table 2). In Iringa, the difference in the number of cut stumps and removed timber volumes (new and old) between reserves was small, but high in Morogoro. Ocotea usambarensis was the most harvested tree species in Iringa and Cedrela odorata, Milicia excelsa, Combretum molle and Albizia petersiana were the most harvested species in Morogoro.

Table 2. Comparison of forest disturbance (number of stumps and volume of Timber removed; mean \pm standard error) between FRs with and without JFM in Iringa and Morogoro, Tanzania.

\begin{tabular}{|c|c|c|c|c|c|c|c|}
\hline \multirow[b]{2}{*}{$\begin{array}{l}\text { Forest } \\
\text { Reserves }\end{array}$} & \multirow[b]{2}{*}{ Regime } & \multicolumn{2}{|l|}{ New stumps } & \multicolumn{2}{|l|}{ Old stumps } & \multicolumn{2}{|l|}{ All stumps } \\
\hline & & $\begin{array}{l}\text { No. } \\
\left(\text { stems ha }{ }^{-1}\right)\end{array}$ & $\begin{array}{l}\text { Volume } \\
\left(\mathrm{m}^{3} \mathrm{ha}^{-1}\right)\end{array}$ & $\begin{array}{l}\text { No. } \\
\left(\text { stems ha }^{-1}\right)\end{array}$ & Volume $\left(\mathrm{m}^{3} \mathrm{ha}^{-1}\right)$ & $\begin{array}{l}\text { No. } \\
\left(\text { stems ha }^{-1}\right)\end{array}$ & Volume $\left(\mathrm{m}^{3} \mathrm{ha}^{-1}\right)$ \\
\hline \multicolumn{8}{|l|}{ Iringa region } \\
\hline $\mathrm{KL}(\mathrm{n}=46)$ & Non JFM & $1.0 \pm 0.43$ & $0.2 \pm 0.03$ & $6.0 \pm 3.28$ & $126.4 \pm 5.64$ & $7.0 \pm 3.28$ & $126.6 \pm 4.91$ \\
\hline \multicolumn{8}{|c|}{ Morogoro region } \\
\hline $\begin{array}{l}\text { Kimboza } \\
(n=33)\end{array}$ & JFM & $4.0 \pm 1.64$ & $2.7 \pm 0.21$ & $34.0 \pm 14.55$ & $49.4 \pm 1.69$ & $38.0 \pm 14.36$ & $52.1 \pm 1.19$ \\
\hline Ruvu (n=35) & Non JFM & $2.0 \pm 1.46$ & $2.5 \pm 0.61$ & $2.0 \pm 0.76$ & $13.2 \pm 2.12$ & $4.0 \pm 1.58$ & $15.7 \pm 1.26$ \\
\hline
\end{tabular}

Note: NDU = New Dabaga Ulongambi, KL = Kising`a-Lugalo

Results in Table 2 show that FRs with JFM regime had slightly higher removed volumes per ha than those without
JFM but the difference was statistically not significant $(p=0.4752)$ and $(p=0.4879)$ for Kimboza/Ruvu and NDU/KL 
FRs respectively. Removed volume for both new and old cut trees was also statistically not significant. The removal rates obtained in the current study are sustainable as they do not exceed the mean annual increments (MAI) of $2.6-7.2 \mathrm{~m}^{3} / \mathrm{ha}^{-}$ ${ }^{1} \mathrm{y}^{-1}$ reported in these sites by Allen [25]. It can therefore be generalized that the disturbances (new removals) in FRs with JFM are not bad to interfere sustainability of forest ecological services if at all they are to be maintained at the same level. According to the intermediate disturbance theory, these removals are good since the forests are managed mainly for provision of ecological services primarily water and biodiversity. The intermediate disturbance theory argues that disturbances renew resources at a rate sufficient to allow continued recruitment and persistence of species that would otherwise be excluded [26]. The theory states that periodic or recurrent disturbance at intermediate level, perpetuate both pioneer and primary species. Under such conditions, species with different life history are able to co-exist and consequently high levels of species richness are maintained. If the intensity of disturbance increases beyond the intermediate level, only colonizing species with high growth or dispersal rates, pioneer species are able to co-exist. This represents lower species diversity. On the other hand, if the disturbances decreases beyond the intermediate level, only the highly competitive climax species which are better at maintaining resources would exist and equilibrium would eventually be attained. Other less competitive species would be excluded and consequently species richness would be maintained at a lower level. However, care should be taken in Morogoro sites since the average removals are already at the minimum mean annual increment value.

The most harvested tree species in NDU and KL FRs was Ocotea usambarensis and Macaranga kilimandscharica that were used for timber while in Kimboza and Ruvu FRs were Cedrela odorata, Combretum molle and Albizia petersiana which were also used for timber and poles. Combretum molle was also reported among the tree species with largest volume of illegally harvested trees in Kitulangalo FR a nearby woodlands in Morogoro [21]. The montane sites in Iringa were less disturbed (fewer new cuts) than in the Morogoro sites, probably because most households in the montane area owned private woodlots for domestic and commercial supply of timber, building poles and firewood [27]. Sale of wood increased household income which eventually reduced pressure on FRs. In the Morogoro sites woodlots were not common, the forests were easily accessed by road due to its flat terrain, and the sites are close to Dar es Salaam city (about $200 \mathrm{~km}$ ), the major timber market in the country. The small fines charged for offenders in the Morogoro could be another factor that acted as an incentive for not stopping illegal harvesting. Most old cut stumps recorded in Kimboza were 3 years old on average, indicating recent pressure. In contrast, the sites in Iringa were all situated in mountains with difficult terrain and they were far from commercial centres. Higher fines set for offenders and responsible village leadership were probably restricting engagement in illegal business. This observation suggests that it is more profitable to invest in woodlots than in JFM in this region. High old cut volumes recorded in the montane region which increased the $\mathrm{R} / \mathrm{S}$ ratio was probably due to recorded old tree stumps that were cut before the government banned harvesting in Catchment FRs in 1992.

The average annual removal of timber was $0.34 \mathrm{~m}^{3} / \mathrm{ha}^{-1} \mathrm{y}^{-1}$ from Iringa and $2.59 \mathrm{~m}^{3} / \mathrm{ha}^{-1} \mathrm{y}^{-1}$ from Morogoro forests. The removal/standing $(\mathrm{R} / \mathrm{S})$ stock ratios were 0.75 in NDU and 1.17 in KL FR (Tables 1 and 2). Despite of high R/S ratio contributed by old removals, the new cut volumes were quite small. The R/S ratio was 0.26 for Kimboza and 0.15 for Ruvu FRs. The disturbance survey also revealed that forest boundaries for all FRs were not clearly demarcated. Most portions with unclear boundaries were encroached for agriculture. Livestock grazing was common in the northern part of Ruvu FR. Old and new signs of fire damage were observed in many parts of Kimboza and Ruvu FRs. Fire incidences were however not observed in any of the Iringa sites.

Three fresh charcoal burning sites targeting Combretum molle (Figure 5b) and 87 mining pits mainly for alluvial gold were recorded in Ruvu FR. Both illegal and licensed small artisans were found mining in the reserve (Figure $5 \mathrm{c}$ ). Hunting was observed in almost all the FRs, but was recorded more in Iringa sites with 11 manila snares in NDU FR and seven in KL FR. One iron snare for catching large mammals was recorded along the boundary of NDU FR. Photos in figure 4 and 5 show some of these disturbances.

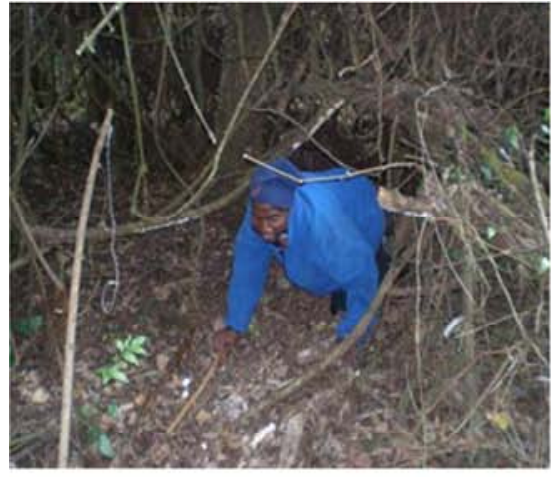

Figure 4(a)

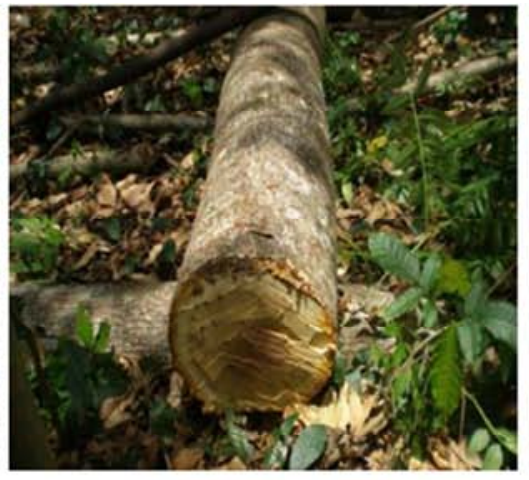

Figure 4 (b)

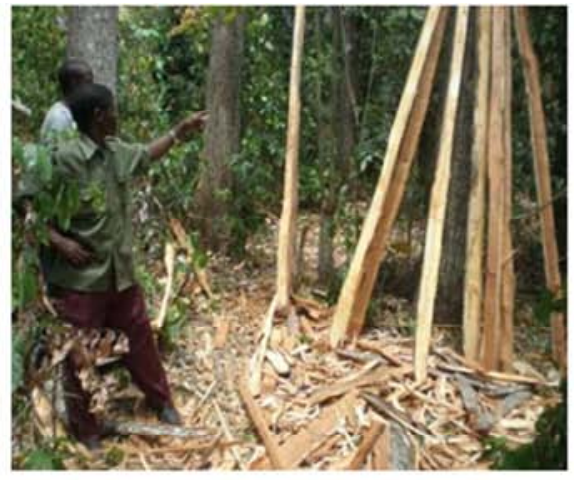

Figure 4 (c)

Figure 4. Illegal resource use in the study FRs in Tanzania: (a) A manila snare showing illegal hunting of small animals in NDU FR, Iringa; (b) Milicia excelsa timber harvested in Kimboza FR, Morogoro; (c) Extraction of Cedrela odorata planks in Kimboza FR, Morogoro. 


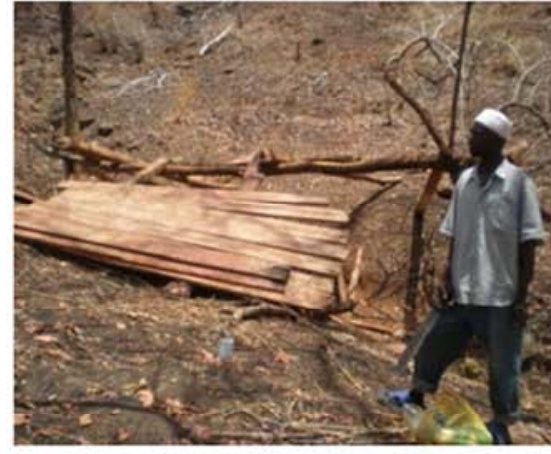

Figure 5(a)

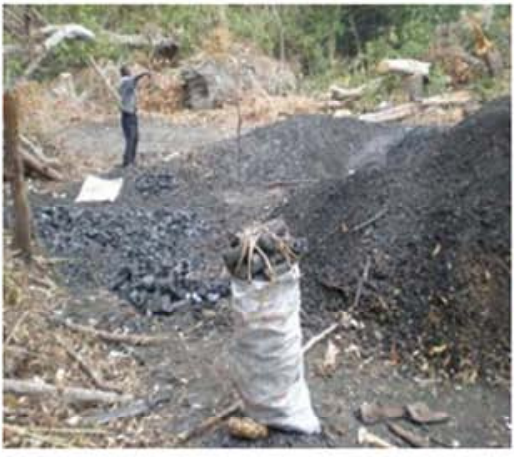

Figure 5 (b)

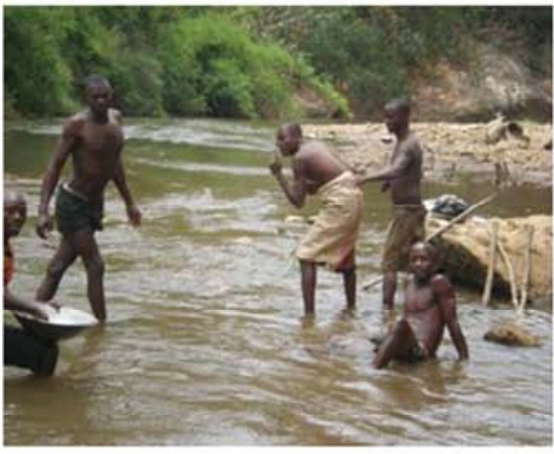

Figure 5 (c)

Figure 5. Illegal resource use in Ruvu FR, Morogoro: (a) Timber harvesting; (b) Charcoal making; (c) Gold mining in Ruvu River.

\subsection{Institutional Analysis}

In principle, all FRs in Tanzania are governed by formal rules as stipulated in the Forest Act No. 14 of 2002. In addition, reserves with JFM arrangements are governed by village by-laws. The study revealed that all four villages had by-laws and JMAs. About $95.7 \%$ of respondents $(\mathrm{N}=164)$ were aware of existence and use of by-laws in their villages. However, complaints were raised during group discussions that the by-laws were outdated. In Morogoro villages for example, by-laws were not revised since their formulation in 2000. In Iringa villages, they were revised once but were not approved by the Ministry of Natural Resources and Tourism. Group discussions with elders revealed that communities did not have informal or traditional rules used to regulate access in the catchment FRs. Under JFM, law enforcement was vested in the village through a Village Natural Resources Committee (VNRC). The committee controlled access and utilization of forest resources with some technical backstopping from foresters. By-laws stipulated fines/penalties for forest offences. Culprits were sanctioned by the village council leadership and primary courts for offences above the capacity of village bylaws. However, the latter was not preferred because it was expensive for villagers to run cases and all the fines charged thereafter went to the central government with no retention scheme. The fines ranged between Tsh $3000 /=$ to Tsh 50 $000 /=$ in Morogoro and Tsh $15000 /=$ to Tsh $50000 /=$ in the Iringa. ( $1 \mathrm{USD}=1400$ Tsh) (Table 3 and 4). In all the study sites, $50 \%$ of the charged fines were used for conservation activities including establishment of tree nurseries, boundary cleaning, fire control etc. The remaining $50 \%$ was used for community development activities by the village council including building classrooms and health centres. Confiscated equipments were sold in auction and funds obtained were also used for conservation.

Table 3. Recorded cases of forest offenses and action taken by village administration in Kibangile village adjacent to Kimboza FR in Morogoro, Tanzania since 2003 to April, 2010. (1 USD = 1400 Tsh.).

\begin{tabular}{lll}
\hline Date & Offense & Fine/action taken \\
\hline $25 / 5 / 2003$ & Harvesting poles, ropes and caught with several animal traps & Products confiscated and auctioned, traps destroyed \\
$4 / 6 / 2004$ & Harvesting Bamboo and caught with several animal traps & Products confiscated and auctioned, traps destroyed \\
$17 / 6 / 2004$ & Harvesting 30 pieces of timber & Fined Tsh $25000 /=$ and all timber confiscated \\
$12 / 1 / 2006$ & Harvesting Bamboo & Fined Tsh $15000 /=$ and Bamboo confiscated \\
$19 / 10 / 2006$ & Harvested 25 pieces of timber & Fined Tsh $55000 /=$ and timber confiscated \\
$25 / 11 / 2007$ & Killed a wild animal & Fined Tsh $20000 /=$ \\
$28 / 09 / 2008$ & Caught with 34 bamboo baskets & Fined Tsh $15000 /=$ \\
$27 / 08 / 2008$ & Caught with poles & Fined Tsh $3000 /=$ and poles confiscated \\
$23 / 09 / 2008$ & Harvesting 5 bamboo & Fined Tsh $15000 /=$ and bamboo confiscated \\
$22 / 10 / 2008$ & Harvesting 1 bamboo & Fined Tsh $3000 /=$ and bamboo confiscated \\
$8 / 4 / 2010$ & Harvesting timber & Fined Tsh $50000=$ and timber confiscated \\
\hline
\end{tabular}

Note: These were cases that were recorded in the VNRC monitoring books. According to village leaders, there were several of such cases that were not recorded in the books due to lack of patrols, for example in 2009 and 2010.

Table 4. Recorded cases of forest offenses and action taken by village administration in Changa village adjacent to Kimboza FR in Morogoro, Tanzania since 2001 to September, 2010. (1 USD = 1400 Tsh.).

\begin{tabular}{lll}
\hline Date & Offense & Fine/action taken \\
\hline $8 / 11 / 2001$ & Causing forest fire in Kimboza FR & Fire was extinguished; offender not known \\
$19 / 09 / 2002$ & Causing forest fire in Kimboza FR & Fire was extinguished; offender not known \\
$16 / 10 / 2002$ & Causing forest fire in Kimboza FR & Fire was extinguished; offender not known \\
$20 / 09 / 2003$ & Charcoal making inside Kimboza FR & The offender was sent to court and jailed for 7 years. \\
$13 / 10 / 2004$ & Causing forest fire in Kimboza FR & Offender was caught but action taken was not recorded \\
$26 / 09 / 2005$ & Forest fire near Sanali sub village. & Fire could not be extinguished as it was so large. \\
\hline
\end{tabular}




\begin{tabular}{lll}
\hline Date & Offense & Fine/action taken \\
\hline $03 / 10 / 2005$ & Causing forest fire near Kimboza FR & Fire was extinguished; offender not known \\
$16 / 2 / 2006$ & Twenty two pieces of timber illegally harvested in FR & All 22 pieces were taken to village office and used for making school desks \\
$05 / 08 / 2006$ & Tree planks were found in FR & All planks were auctioned and funds used for conservation activities \\
$26 / 03 / 2007$ & Harvesting Cedrela timber in Kimboza FR & Fined Tsh 30 000/= and timber confiscated \\
$12 / 09 / 2007$ & Causing forest fire in Kimboza FR & Fire was extinguished; offender not known \\
$23 / 08 / 2010$ & Lorry with Cedrela logs caught & Fined Tsh 1000 000/= and logs confiscated \\
\hline
\end{tabular}

Note: These were cases that were recorded in the VNRC monitoring books. According to village leaders, there could be several of such cases that were not recorded in the books due to lack of patrols, for example between 2008 and 2010.

During the field work, Kimboza FR had no forester to work with VNRC. Irresponsible village leadership which failed to conduct quarterly meetings and increased forest boundary conflicts between villages adjacent to Kimboza FR were of concern. This weakness could also be traced in Table 3 and 4 where enforcement of rules was weak in 2008 and 2009. The disturbance survey revealed tree cuttings in these years and group discussions witnessed that VNRCs were not doing patrols as required. The protection by VNRC was just de jure but in reality the power of VNRCs was negligible because they were not respected by society members. VNRCs acknowledged that they did not enforce by-laws effectively due to lack of motivation (payment or exceptions from other community development activities), a fact that sometimes led to corruption [15]. According to Ostrom [10], most rules work when they are enforced. The absence of a forester in Kimboza was also a disincentive to VNRC. Therefore, the forest disturbances in Kimboza FR may be interpreted as an indication of institutional failure, and as a result of weak protection by both VNRCs and foresters.

In India and Nepal for example, restricted access to catchment forests has been reported to affect forest users and there was evidence that JFM in India had not been successful [28]. Until recently, Nepal had no study done to see whether forest disturbances have increased or decreased [29]. It is however reported that the FRs became more accessible after management responsibility was handed over to local communities [30]. Adhikari et al., [31] reported that when forests were under a strict protection, disturbance was reduced and it increased as it became more accessible. Among other factors, JFM was established in Tanzania to improve forest governance. But despite all the regulations, disturbances continued indicating that JMAs were not effective measures to reduce or stop illegal harvesting.

\subsection{Weak Compliance of Rules}

It has been argued by other authors (e.g. Acheson, [32]; Maximillian and O'Laughlin, [18] that effort to conserve forests fails because local communities either cannot devise operational rules or because the operational rules fail after they are established. For Kimboza FR, it was clear that both collective choice and constitutional rules at village level had collapsed and also made operational rules ineffective. VNRCs have failed to enforce the rules as illegal harvesting increased despite the existence of by-laws. According to Acheson [32], one cause of forest depletion is that people may not recognize that resources are being depleted particularly in the first stages of overexploitation. Factors making the process of enforcing rules cumbersome in Kimboza include lack of motivation (e.g. VNRC were not paid for patrolling work), high dependence on FRs, weak leadership (villagers and forest officers), lack of alternative income sources and unmanaged forest boundaries. Some of these factors are also reported elsewhere (e.g. North, [33]; Ostrom, [10]; Ostrom, [34]. Unresolved issues of cost and benefit sharing between Government and local communities, growing population, increased income-poverty, emerging timber markets and weakening of traditional rules as shown by various authors (e.g. Aswani, [35]; Rose, [36] are also contributing to low compliance.

\section{Conclusion}

It is concluded that community participation in forest management is a wealthy undertaking. Participation has shown to improve stocking level of forest resources. Also levels of tree cutting reported for both regimes (with and without JFM) were considered sustainable because they are below mean annual increment and ecologically are considered beneficial to the forest in terms of stimulating regeneration of the harvested tree species. The study has also proved that JFM leads to improvement in resource base but not necessarily improve forest governance. Rules and agreements were ineffective for stopping illegal activities in JFM. The high level of rules compliance in villages surrounding NDU FR in Iringa reflected the viability of local institution structures. These findings give some indications to the policy for taking corrective measures for scaling up JFM to other parts in the country.

\section{References}

[1] Rogers, C. P., O'connell, B., Mwang'ombe, J., Madoffe, S. S. \& Hertel, G. (2008). Forest health monitoring in the Ngangao forest, Taita hills, Kenya: A five year assessment of change. Journal of East African Natural History. 97(1): 3-17.

[2] Rogo, L., Oguge, N. (2000). The Taita Hills forest remnants: a disappearing world heritage. Ambio 29: 522-523.

[3] Madoffe, S., Hertel, G. D., Rogers, P., O'connell, B.\& Killenga, R. (2006). Monitoring the health of selected eastern arc forests in Tanzania. African Journal of Ecology 44: 171177.

[4] Forest and Beekeeping Division. (2005). Forest condition assessment of the Eastern Arc Mountains Forests of Tanzania. Forestry and Beekeeping Division, Dar es Salaam, Tanzania. 
[5] Bracebridge, C. (2006). Mkindo Forest Reserve: Forest disturbance report for Tanzania Forest Conservation Group and Participatory Environmental Management Programme, Dar es Salaam, Tanzania.

[6] Ylhäisi, J. (2003). Forest privatization and the role of community in forests and nature protection in Tanzania. Environmental Science and Policy 6: 279-290.

[7] Zahabu, E., Eid, T., Kajembe, G. C., Mbwambo, L., Mongo, C., Sangeda, A. Z., Malimbwi, R. E., Katani, J. Z., Kashaigili, J. J. and Luoga, E. J.(2010). Forestland tenure systems in Tanzania: an overview of policy changes in relation to forest management. INA-report no. 14, $24 \mathrm{p}$.

[8] Malimbwi, R. E., Munyanziza, E. (2004). From local people to local people: forest management and policy in Tanzania over 100 years. UNISWA Research Journal of Agriculture, Science and Technology 7(2): 101-108.

[9] Mniwasa, E., Shauri, V. (2001). Review of the decentralization process and its impact on environment and natural resources management in Tanzania.

[10] Ostrom, E. (1990). Governing the Commons: The Evolution of Institutions for Collective Action. Cambridge, UK: Cambridge University Press.

[11] Adams, W., Hulme, D. (2001). Conservation and Community. In: Hulme D, Murphree M (Eds.) African Wildlife and Livelihoods. James Currey Limited Oxford.

[12] Kajembe, G. C., Ngaga, Y. M. \& Chamshama, S. A. O. (2008). Participatory Forest Management in Tanzania: Opportunities, Challenges and Lessons Learned. Paper Presented at CERES Seminar, Wageningen, The Netherlands.

[13] United Republic of Tanzania. (2008). Participatory Forest Management in Tanzania. Facts and figures. Extension and Public Unity, Forestry and Beekeeping Division, Ministry of Natural Resources and Tourism, Dar es Salaam. pp 6-10.

[14] Meshack, C. K., Ahdikari, B., Doggart, N. \& Lovett, J. C. (2006). Transaction costs of community-based forest management: empirical evidence from Tanzania. African.

[15] Brockington, D. (2007). Forests, community conservation, local government performance: the village forest reserves of Tanzania. Society and Natural Resources 20: 835-848.

[16] Wily, L. A. (2002). The political economy of community forestry in Africa-Getting the power relations right. Forest, Trees and People Newsletter 46: 4-12.

[17] Sauer, J., Abdallah, J. M. (2007). Forest Diversity, tobacco production and resource management in Tanzania. Forest Policy and Economics 9(5): 421-439.

[18] Maximillian, J. R., O'laughlin, J. (2009). Toward sustainable harvesting of Africa's largest medicinal plant export (Prunus africana): a case study in Tanzania. Southern Forests 71(4): 303-309.

[19] Malimbwi, R. E., Mugasha, A. G. (2001). Reconnaissance inventory report of Handeni Forest Reserve in Tanga, Tanzania.

[20] Philip, M. S. (1994). Measuring trees and forests. University press Cambridge (2nd edn). $310 \mathrm{p}$.

[21] Luoga, E. J., Witkowski, E. T. F.\& Balkwill, K. (2002). Harvested and standing wood stocks in protected and communal miombo woodlands of Eastern Tanzania. Forest Ecology and Management 164: 15-30.

[22] Chamshama, S. A. O., Mugasha, A. G., Zahabu, E. (2004). Stand Biomass and Volume Estimation for Miombo Woodlands at Kitulangalo, Morogoro, Tanzania. Southern African Forest Journal 200: 59-64.

[23] Augspurger, C. K. (1984). Light requirements. A comparative study of growth and survival. Ecology 72: 777-972.

[24] Chadzdon, R. L., Robert, W. P. (1991). The importance of sun flakes for forest understory plant. Bioscience. 41: 760-744.

[25] Allen J. C. (1986). Soil properties and fast growing tree species in Tanzania. Forest ecology and Management 16(1-4) 127-147.

[26] Hobbie, S. E., Jensen, D. B. \& Chapin, F. S. (1994). Resource supply and disturbance as controls over present and future plant diversity. In: Schulze, E. D. and Mooney, H. A. (Eds.). Biodiversity and ecosystem function. Ecological studies 99, Springer-Verlag, Berlin. pp. $385-408$.

[27] Lugandu, S. D. (2010). The impact of joint forest management on rural community livelihoods, forest cover and transaction costs: A case study of New Dabaga Ulongambi Forest Reserve in Kilolo District, Tanzania. $\mathrm{PhD}$ thesis submitted in fulfillment for the degree of doctor of philosophy of the open University of Tanzania.

[28] Malla, Y. B. (2000). Impact of community forestry policy on rural livelihoods and food security in Nepal. Unasylva 51 (3): $37-45$.

[29] Springate-Baginski, O., Soussan, J. G., Dev, O. P., Yadav, N. P., Kiff, E. (1999). Community Forestry in Nepal: Impacts on Common Property Resource Management, School of Environment and Development, Series, vol. 3. University of Leeds, UK.

[30] Poffenberger, M., Mcgean, B. (1998). Village voices, forest choices. Joint Forest Management in India. Oxford University press. New delhi. pp17-55.

[31] Adhikari, B., Williams, F., Lovett, J. C. (2005). Local benefits from community forests in the middle hills of Nepal. Forest Policy and Economics. 9: 464-478.

[32] Acheson, J. M. (2006). Institutional Failure in Resource Management. Annual Review of Anthropology 35: 117-134.

[33] North, D. (1990). Institutions, Institutional Change and Economic Performance. Cambridge, UK: Cambridge University Press.

[34] Ostrom, E. (2000). Collective action and the evolution of social norms. Journal of Economic Perspectives 14(3): 13758.

[35] Aswani, S. (2002). Assessing the effects of changing demographics and consumption patterns on sea tenure regimes in the Roviana Lagoon, Solomon Islands. Ambio 31(4): 272 84.

[36] Rose, C. M. (2002). Common property, regulatory property, and environmental protection: comparing community-based management to tradable environmental allowances. In: Ostrom, E., Dietz, T., Dolsak, N., Stern, P., Stonich, S. (Eds.). The Drama of the Commons, EU Weber, Washington, DC: National Academies Press pp. 233-257. 